\title{
LGL1 lipid in myeloma: A greasy affair
}

\author{
Prabir K Chakraborty*
}

Department of Pathology, The University of Oklahoma Health Sciences Center, Oklahoma City, Oklahoma, USA

An altered lipid metabolism leading to increasing lipogenesis in cancerous tissues has long been recognized as an important property of transformed cells and, consequently, metabolic pathways involved in lipid biogenesis are emerging out to be important therapeutic targets [1-6]. However, mechanisms through which cancer cells rewire metabolic pathways to enhanced lipogenesis are only poorly understood. In the last decade, the altered lipid metabolism pathways has increasingly been recognized to be related to increases in the incidence of a number of cancers such as breast, colorectal, prostate, ovary, including myeloma [7-12]. To meet the increasing demand of lipids, cancer cells rewire lipid metabolism through so far poorly understood mechanisms. These lipids are necessary as membrane constituents to support incessant cellular proliferation, an energy source to support indefinite proliferative potential and as a reservoir for fuelling unstoppable oncogenic signaling. This involves enhancement of endogenous lipogenesis via elevating expression of a number of key lipogenic enzymes such as ATP citrate lyase (ACLY), acetylCoA carboxylase (ACC), fatty acid synthase (FASN) and promoting exogenous lipid uptake [1,3,13-15]. Lipids in the cells are usually stored in the form of lipid droplets [16-18] (LDs) and it can be speculated that cancer cells utilize LDs as reservoir for "on demand" release of lipids, mechanisms of which are currently elusive. However, given the recognition that lipids play critical roles in the pathogenesis of various cancers including myeloma, limiting lipid availability holds promise to improve dismal prognosis in myeloma. First described in 1848, multiple myeloma $(\mathrm{MM})$ is a crippling malignancy that is part of a spectrum of diseases ranging from monoclonal gammopathy of unknown significance (MGUS) to plasma cell leukemia. MM is characterized by a proliferation of malignant plasma cells and a subsequent overabundance of monoclonal paraprotein (M protein) [19]. The uncontrolled growth of these cells leads to pathologic fractures, bone pain, neuropathies, hypercalcemia and spinal cord compression. Though several new FDAapproved therapies are implemented in myeloma, the mortality rate is alarmingly high, whilst the cause of myeloma has remained elusive until now [19].

In this context, a recent finding by a group of researchers led by Prof. Madhav Dhodapkar from the Yale University was published in the February 11 issue of the New England Journal of Medicine described that chronic stimulation of the immune system by lipids made in the context of inflammation underlies the origins of at least one-third of all myeloma cases [20]. The researchers identified the myeloma clonal immunoglobulin was associated with transformed plasma cells which exhibited reactivity against lysolipids, lysoglucosylceremide (LGL1) and lysophosphatidylcholine (LPC) [20]. They forwarded the hypothesis that Gaucher's disease (an inherited lipid-storage disorder) is a genetic clue linking lipids with myeloma. Since patients with Gaucher's disease have an accumulation in lipids due to a glucocerebroside deficiency, leads to increased levels of the LGL1 causing myeloma being the common cancer seen in survivors of Gaucher's disease. The new findings is based on previous research from Dhodapkar's laboratory demonstrating a sub-population of lipid sensitive immune cells, called type II NKT-TFH cells, involved in the development of plasma cells [21] and patients with Gaucher disease have a significant increased risk for developing myeloma.

In this study, the researchers employed tissue and blood samples from both mice and patients to establish that the immunoglobulins made by transformed plasma cells recognize specific lipids. More specifically, clonal immunoglobulin in 17 of 20 patients with Gaucher's disease and in 6 of $6 \mathrm{GBA1}^{-/-}$mice (which faithfully recapitulate type 1 Gaucher's disease in humans) with monoclonal gammopathy were specific for LGL1. LGL1 reactivity was also observed for Gaucher's disease-associated polyclonal gammopathy. In contrast, only low-level or background reactivity was detected in samples obtained from healthy donors or control mice [20]. These studies open newer avenues to intervene the levels of immunoreactive-lipids in patients with Gaucher disease and/or myeloma. According to Dr. Dhodapkar, reducing the lipid levels could be achieved with drugs or lifestyle changes and hence lowers the risk of cancer [22]. This is an elegant study and holds the potential in translating these observations for therapeutic interventions and posits a direct link to myeloma, inflammation and metabolic disorders, including obesity.

\section{References}

1. Baenke F, Peck B, Miess H, Schulze A (2013) Hooked on fat: the role of lipid synthesis in cancer metabolism and tumour development. Dis Model Mech 6: 1353-1363. [Crossref]

2. Santos CR, Schulze A (2012) Lipid metabolism in cancer. FEBS J 279: 2610-2623 [Crossref]

3. Currie E, Schulze A, Zechner R, Walther TC, Farese RV Jr (2013) Cellular fatty acid metabolism and cancer. Cell Metab 18: 153-161. [Crossref]

4. Zhang F, Du G (2012) Dysregulated lipid metabolism in cancer. World J Biol Chem 3 : 167-174. [Crossref]

5. Pyragius CE, Fuller M, Ricciardelli C, Oehler MK (2013) Aberrant lipid metabolism: an emerging diagnostic and therapeutic target in ovarian cancer. Int J Mol Sci 14: 77427756.[Crossref]

6. Cantor JR, Sabatini DM (2012) Cancer cell metabolism: one hallmark, many faces Cancer Discov 2: 881-898. [Crossref]

7. Nomura DK, Cravatt BF (2013) Lipid metabolism in cancer. BiochimBiophysActa 1831: 1497-1498. [Crossref]

8. Baumann J, Sevinsky C, Conklin DS (2013) Lipid biology of breast cancer. Biochim Biophys Acta 1831: 1509-1517. [Crossref]

Correspondence to: Prabir K Chakraborty, Department of Pathology, The University of Oklahoma Health Sciences Center, Oklahoma City, Oklahoma, USA, E-mail: Prabir-Chakraborty@ouhsc.edu

Received: February 28, 2016; Accepted: March 21, 2016; Published: March 24, 2016 
9. Zadra G, Photopoulos C, Loda M (2013) The fat side of prostate cancer. BiochimBiophysActa 1831: 1518-1532. [Crossref]

10. Tania M, Khan MA, Song Y (2010) Association of lipid metabolism with ovarian cancer. CurrOncol 17: 6-11. [Crossref]

11. Melvin JC, Seth D, Holmberg L, Garmo H, Hammar N, et al. (2012) Lipid profiles and risk of breast and ovarian cancer in the Swedish AMORIS study. Cancer Epidemiol Biomarkers Prev21: 1381-1384.

12. Sasagawa T, Okita M, Murakami J, Kato T, Watanabe A (1999) Abnormal serum lysophospholipids in multiple myeloma patients. Lipids 34: 17-21. [Crossref]

13. Muñoz-Pinedo C, El Mjiyad N, Ricci JE (2012) Cancer metabolism: current perspectives and future directions. Cell Death Dis 3: e248. [Crossref]

14. Ackerman D, Simon MC (2014) Hypoxia, lipids, and cancer: surviving the harsh tumor microenvironment. Trends Cell Biol 24: 472-478. [Crossref]

15. Turrado C, Puig T, García-Cárceles J, Artola M, Benhamú B, et al. (2012) New synthetic inhibitors of fatty acid synthase with anticancer activity. $J$ Med Chem 55 5013-5023. [Crossref]
16. Bozza PT, Viola JP (2010) Lipid droplets in inflammation and cancer. Prostaglandins LeukotEssent Fatty Acids 82: 243-250. [Crossref]

17. Thiam AR, Farese RV Jr, Walther TC (2013) The biophysics and cell biology of lipid droplets. Nat Rev Mol Cell Biol 14: 775-786. [Crossref]

18. Greenberg AS, Coleman RA, Kraemer FB, McManaman JL, Obin MS, et al. (2011) The role of lipid droplets in metabolic disease in rodents and humans. J Clin Invest 121: 2102-2110. [Crossref]

19. Boyle EM, Davies FE, Leleu X, Morgan GJ (2014) Understanding the multiple biological aspects leading to myeloma. Haematologica 99: 605-612. [Crossref]

20. Nair S, Branagan AR, Liu J, Boddupalli CS, Mistry PK, et al. (2016) Clonal Immunoglobulin against Lysolipids in the Origin of Myeloma. N Engl J Med 374: 555561. [Crossref]

21. Nair S, Boddupalli CS, Verma R, Liu J, Yang R, et al. (2015) Type II NKT-TFH cells against Gaucher lipids regulate B-cell immunity and inflammation. Blood 125: 12561271. [Crossref]

22. http://www.medscape.com/viewarticle/858906

Copyright: (C2016 Chakraborty PK. This is an open-access article distributed under the terms of the Creative Commons Attribution License, which permits unrestricted use, distribution, and reproduction in any medium, provided the original author and source are credited. 